\title{
KEDUDUKAN IKATAN JUAL BELI DENGAN KUASA MENJUAL SEBAGAI JAMINAN UTANG DI LINGKUNGAN KOPERASI SIMPAN PINJAM
}

\author{
Diana Hugeng \\ Fakultas Hukum Universitas Surabaya \\ E-mail: hugengdiana@gmail.com
}

\begin{abstract}
Tangible collateral as part of Tangible Law (Hukum Benda) has a nature of close and enforcing (dwingend recht). It is limiting and prohibiting anyone that will make tangible collateral in a form other than what has been stipulated in the prevailing laws. In relation to loan collateral in form of certificate of right over the land, since the effective date of the Law of the Republic of Indonesia No.4 Year 1996 concerning Encumberance Right over the Land and Things Related to the Land, the only allowable loan collateral is in the form of Encumberance Right. This means loan collateral made in form of Agreement on Commitment to Sell and Purchase with Power of Attorney to Sell is against the law, therefore it is legally stated as null and void due to violating the objective requirements on the legality of an agreement as stipulated in Article 1320 of Burgerlijk Wetboek. Agreement on Commitment to Sell and Purchase with Power of Attorney to Sell as loan collateral is not only against the Law of the Republic of Indonesia No.4 Year 1996 concerning Encumberance Right over the Land and Things Related to the Land, but also against the Law of the Republic of Indonesia No.25 Year 1992 concerning Cooperative, due to the objective of cooperative based on Article 44 point 1 of Cooperative Law is to raise funding from and provide lending to the members of respective cooperative, as well as other cooperatives and/or their members. In case a debtor being a new member of the cooperative when he or she applying loan to the cooperative, it is not aligned with the basic objective of cooperative.
\end{abstract}

Keywords: Tangible collateral, Loan collateral, Agreement on Commitment to Sell and Purchase, Power of Attorney to Sell, and Cooperative.

\section{Pendahuluan}

Aristoteles menyebut manusia dengan istilah Zoon Politicon, artinya bahwa manusia adalah makhuk sosial yang dikodratkan untuk hidup bermasyarakat dan berinteraksi antara satu dengan yang lainnya. Selain sebagai makhluk sosial, Adam Smith menyatakan bahwa manusia adalah makhluk ekonomi atau yang lebih dikenal dengan istilah Homo Economicus yang artinya bahwa manusia selalu berusaha secara terus menerus memenuhi kebutuhan dan keinginannya. Hal tersebut yang mendorong manusia berinteraksi dengan manusia yang lainnya untuk memenuhi segala jenis kebutuhan hidupnya dengan lebih mudah dan efisien, karena dalam pemenuhan kebutuhannya manusia memiliki keterbatasan baik dalam hal kemampuan, keterampilan, peralatan yang dimiliki dan dalam hal-hal yang lain. Keterbatasan tersebut dapat diatasi apabila manusia mau berinteraksi dengan manusia yang lainnya. Salah satu wujud interaksi tersebut yaitu dalam bentuk hubungan perdagangan. Menurut Isnaeni,manusia saat melakukan interaksi demi memenuhi kebutuhan hidup, agar berhasil, pasti poros perhitungan yang dijadikan batu ukur adalah persoalan untung dan rugi. Bila setiap tindakan selalu didasarkan pada perhitungan untung rugi (compensatio lucri cum damno), inilah sebenarnya merupakan urusan bisnis. Corak seperti itu memang cocok, karena sesungguhnya manusia itu eksistensinya bersosok sebagai homo economicus. Artinya tingkah polah keseharian dalam rangka menjaga keberlanjutan eksistensinya, selalu dilandaskan pada perhitungan untung rugi yang diolah dengan kematangan pola pikir atau berdasar pada kemantapan logika ${ }^{1}$.

Interaksi dalam menjalankan hubungan hukum seringkali dihadapkan pada keterbatasan dana maupun peralatan usaha, sehingga memerlukan bantuan dari sumbersumber pembiayaan, yaitu lembaga pembiayaan (khususnya perbankan) atau perorangan, dengan membuat perjanjian pinjam meminjam (utang piutang). Menurut Adrian Sutedi, dilihat dari sudut ekonomi, kredit diartikan sebagai penundaan

\footnotetext{
1 Isnaeni, Selintas Pintas Hukum Perikatan, PT
} Revka Petra Media, Surabaya, 2017, h.3. 
pembayaran karena pengembalian atas penerimaan uang dan atau suatu barang tidak dilakukan bersamaan pada saat menerimanya, melainkan pengembaliannya dilakukan pada masa tertentu akan datang2. Seseorang yang memperoleh kredit berarti memperoleh kepercayaan, dengan demikian dasar dari kredit adalah kepercayaan. Menurut Adrian Sutedi, tenggang waktu antara pemberian dan penerimaan kembali prestasi merupakan suatu hal yang abstrak yang sukar diraba, karena masa antara pemberian dan penerimaan prestasi tersebut dapat berjalan dalam beberapa bulan, tetapi dapat pula berjalan beberapa tahun ${ }^{3}$. Ketentuan yang mengatur mengenai kewajiban penerima kredit terdapat dalam Pasal 1763 dan 1764 Burgerlijk Wetboek (selanjutnya disebut BW). Ketentuan Pasal 1763 BW menyatakan bahwa kewajiban pokok peminjaman adalah mengembalikan pinjaman dalam jumlah dan keadaan yang sama, dan pada waktu yang ditentukan, sedangkan Pasal 1764 BW mengatur kewajiban peminjam bila yang dipinjam adalah barang.

Pada praktek pemberian jaminan kebendaan, tidak jarang tanah dan bangunan dengan bukti hak Sertifikat Hak Milik dijadikan agunan pembayaran utang. Mengingat pentingnya tanah dan bangunan bagi kehidupan perorangan dan juga memperhatikan praktek jaminan kebendaan dengan menggunakan tanah dan bangunan tersebut, maka aturan mengenai jaminan kebendaan sangatlah penting. Apabila ditinjau dari sifat hukum benda sebagai induk jaminan kebendaan, maka sifatnya jaminan kebendaan adalah tertutup, artinya tidak dimungkinkan membuat bentuk jaminan kebendaan lain diluar apa yang telah ditentukan oleh peraturan perundangundangan yang berlaku. Menjamin adanya kepastian hukum sudah seharusnya sifatnya adalah memaksa, dalam arti tidak dapat disimpangi atau dikesampingkan kendati dengan adanya kesepakatan sekalipun. Aturan tentang benda dengan karakter menjamin adanya kepastian hukum tersebut hanya dapat dikemas dalam tataran ketentuan hukum dengan ciri sebagai dwingend recht. Dimana aturan di Indonesia mengenai hal tersebut terlihat dalam Buku II

\footnotetext{
2 Adrian Sutedi, Hukum Hak Tanggungan ,Sinar Grafika, Jakarta, 2010, h.19.

3 Ibid, h.21.
}

BW yang didominasi oleh dwingend recht. Hal tersebut merupakan salah satu alasan yang mengakibatkan Buku II BW tersebut memiliki sifat tertutup. Ketentuan yang terdapat dalam Buku II BW tersebut yang harus berlaku sebagai satu-satunya aturan tentang pengertian benda, tanpa ada kemungkinan para pihak membuat aturan tandingan berdasarkan kesepakatan.

Ketentuan mengenai pembatasan lembaga jaminan kebendaan terhadap tanah dan bangunan dengan bukti hak sertifikat hak milik yang hanya boleh dilakukan dengan membebani Hak Tanggungan juga banyak disimpangi dalam praktik perjanjian hutang piutang yang dilakukan dengan koperasi-koperasi simpan pinjam, dimana hal tersebut juga terkesan dibiarkan oleh putusan-putusan Pengadilan berkaitan dengan hal tersebut, yang secara tidak langsung membenarkan praktek-praktek pembuatan jaminan kebendaan atas tanah dan bangunan dengan bukti hak sertifikat hak milik dalam bentuk kuasa menjual. Tujuan koperasi simpan pinjam berdasarkan Pasal 44 ayat 1 Undang-Undang Nomor 25 Tahun 1992 tentang Perkoperasian (selanjutnya disebut UU Perkoperasian) adalah untuk menghimpun dana dan menyalurkannya melalui kegiatan usaha simpan pinjam dari dan untuk anggota koperasi yang bersangkutan, serta koperasi lain dan/atau anggotanya. Namun seringkali dijumpai Debitor baru menjadi anggota saat berutang kepada koperasi. Hal tersebut menjadi tidak relevan dengan tujuan dasar koperasi.

\section{Metode Penelitian}

Menjawab permasalahan yang telah dirumuskan dalam rumusan masalah, digunakan metode penelitian hukum normatif. Johnny Ibrahim menyatakan bahwa yang dimaksud dengan penelitian hukum normatif adalah suatu prosedur penelitian ilmiah untuk menemukan kebenaran berdasarkan logika keilmuan yang ajeg dalam penelitian hukum normatif, dibangun berdasarkan disiplin ilmiah dan cara-cara kerja ilmu hukum normatif, yaitu ilmu hukum yang objeknya hukum itu sendiri ${ }^{4}$. Sedangkan menurut Peter Mahmud Marzuki, penelitian hukum yaitu suatu

\footnotetext{
4 Johnny Ibrahim, Teori \& Metodologi Penelitian Hukum Normatif, Bayu Media, Surabaya, 2005, h.57.
} 
proses untuk menemukan aturan hukum, prinsip-prinsip hukum, maupun doktrindoktrin hukum guna menjawab isu hukum yang dihadapi ${ }^{5}$.

Dalam penelitian ini, pendekatan masalah yang akan digunakan adalah Conceptual Approach dan Statue Approach atau pendekatan perundang-undangan.

1. Pendekatan Konseptual (Conceptual Approach) yang berdasar dari pandangan dan doktrin yang berkembang dalam Ilmu Hukum sehingga dapat menemukan ideide yang melahirkan pengertianpengertian hukum dan asas serta konsep yang relevan dengan isu yang dihadapi.

2. Pendekatan undang-undang (Statute Approach) dilakukan dengan mengkaji semua undang-undang dan pengaturan yang bersangkut paut dengan isu hukum yang sedang ditangani.

\section{Hasil dan Pembahasan}

Hukum perjanjian (overeenkomst) sebagai bagian dari hukum perikatan yang diatur dalam Buku III BW, berdasarkan Pasal 1313 BW didefinisikan sebagai suatu perbuatan dengan mana satu orang atau lebih mengikatkan dirinya terhadap satu orang lain atau lebih. Syarat sahnya suatu perjanjian menurut Pasal 1320 BW ada 4 (empat) yaitu:

1. sepakat mereka yang mengikatkan dirinya

2. kecakapan untuk membuat suatu perikatan

3. suatu hal tertentu

4. suatu sebab yang halal

Mengingat ketentuan Pasal 1320 BW tentang 4 (empat) syarat sahnya suatu perjanjian seperti yang telah diuraikan di atas, yaitu: sepakat mereka yang mengikatkan dirinya, kecakapan untuk membuat suatu perikatan, suatu hal tertentu, dan suatu sebab yang halal, maka kaitannya dengan Ikatan Jual Beli dengan kuasa menjual sebagai jaminan pembayaran utang, yaitu nampak adanya ketidaksesuaian atas hubungan hukum Ikatan Jual Beli tersebut. Konteks dari Ikatan Jual Beli disini merupakan perjanjian tambahan dari perjanjian pokoknya, yaitu utang-piutang antara para pihak dalam suatu perjanjian kredit. Hal ini berarti unsur ketiga dari Pasal

\footnotetext{
5 Peter Mahmud Marzuki, Penelitian Hukum,
} Prenada Media Group, Jakarta, 2010, h.60.
1320 BW tentang syarat sahnya suatu perjanjian yaitu tentang suatu hal tertentu tidak terpenuhi. Empat syarat sahnya suatu perjanjian di Pasal 1320 BW bersifat komulatif dan bukan alternatif, hal ini berarti tidak terpenuhinya salah satu syarat obyektif ini maka mengakibatkan perjanjian tersebut menjadi batal demi hukum. Namun hapusnya perjanjian tambahan ini tidak serta merta menghapuskan perjanjian kredit sebagai perjanjian pokoknya. Debitor tetap berkewajiban memenuhi prestasi dan Kreditor tetap berhak menerima pemenuhan atas prestasi tersebut.

Hak Tanggungan diatur dalam UndangUndang nomor 4 tahun 1996 yang diterbitkan sebagai pelaksanaan dari Pasal 51 dan Pasal 57 Undang-Undang nomor 5 tahun 1960 mengenai Pokok Agraria (selanjutnya disebut UUPA). Ketentuan Pasal 51 UUPA menyatakan "Hak Tanggungan yang dapat dibebankan pada hak milik, hak guna usaha, dan hak guna bangunan tersebut dalam Pasal 25, Pasal 33, dan Pasal 39 diatur dalam undang-undang." Kemudian dalam Pasal 57 UUPA disebutkan bahwa selama Undang-Undang Hak Tanggungan belum terbentuk, maka digunakan ketentuan tentang hipotek sebagaimana diatur di dalam KUHPerdata dan credietverband. Perintah Pasal 51 UUPA ini terealisasi dengan lahirnya Undang-Undang nomor 4 tahun 1996 tentang Hak Tanggungan setelah 36 (tiga puluh enam tahun) lamanya. Munculnya UU Hak Tanggungan ini dimaksudkan untuk mengakhiri dualisme dalam pengaturan hak jaminan atas tanah yang sebelumnya menggunakan lembaga jaminan hipotik dan credietverband. Melalui Undang-Undang nomor 4 tahun 1996, hak jaminan atas tanah dikonversi dan diunifikasi menjadi Hak Tanggungan. Diberlakukannya UU Hak Tanggungan ini penting dalam menciptakan unifikasi Hukum Tanah Nasional, khususnya di bidang hak jaminan atas tanah. Pasal 1 ayat 6 Ketentuan Konversi UUPA menyatakan bahwa hak-hak hipotik dan credietverband yang telah ada sebelumnya dikonversi menjadi Hak Tanggungan.

Hak Tanggungan tergolong sebagai hak jaminan kebendaan seperti yang dinyatakan oleh $\mathrm{H}$. Moch. Isnaeni dalam bukunya yang berjudul Hukum Jaminan Kebendaan: Eksistensi, Fungsi, dan Pengaturan, bahwa kesamaan identifikasi antara Hak Tanggungan dan Hak Jaminan Kebendaan nampak dengan melihat ciri-ciri unggul hak 
kebendaan dalam UU Hak Tanggungan itu sendiri, yaitu pada uraian Pasal 1 angka 1 UU Hak Tanggungan yang menjelaskan bahwa Hak Tanggungan memiliki ciri preferensi maka pelunasannya harus lebih didahulukan dari kreditor lain, dan sudah selayaknya kalau piutang tersebut digolongkan sebagai piutang istimewa yang memberikan kedudukan yang diutamakan pada kreditornya untuk mempunyai hak didahulukan dalam pelunasan atas piutangnya daripada kreditor-kreditor lainnya atas hasil penjualan benda yang dibebani Hak Tanggungan tersebut ${ }^{6}$, juga pada Pasal 7 UU Hak Tanggungan yang menegaskan tentang sifat droit de suite, selalu mengikuti obyeknya dimana bendabenda yang dijadikan obyek Hak Tanggungan itu tetap terbeban Hak Tanggungan walaupun sudah beralih ke penguasaan subyek hukum yang lainnya ${ }^{7}$ dan sifatnya mengikat. Hak Tanggungan juga memiliki asas spesialisitas ${ }^{8}$ yang ada dalam Pasal 11 ayat 1 huruf e UU Hak Tanggungan, serta asas publisitas dalam hak kebendaan yang disebutkan dalam Pasal 13 UU Hak Tanggungan. Asas spesialisitas artinya bahwa benda yang dibebani Hak Tanggungan itu harus ditunjuk secara khusus, dalam Akta Pemberian Hak Tanggungan harus dibuatkan secara tegas dan jelas mengenai benda yang dibebani itu berupa apa, di mana letaknya, berapa luasnya, apa batasnya, dan apa bukti kepemilikannya. Juga mengandung asas publisitas yang artinya pembebanan Hak Tanggungan tersebut harus dapat diketahui oleh umum ${ }^{9}$, sehingga mendorong pentingnya Akta Pemberian Hak Tanggungan harus didaftarkan. Selain itu juga mengandung asas mudah dan pasti atas pelaksanaan eksekusinya, yang bersifat sama seperti putusan hakim yang berkekuatan hukum tetap. Hak Tanggungan juga bersifat tidak dapat dibagi-bagi, kecuai diperjanjikan dalam Akta Pemberian Hak Tanggungan.

Suatu Hak Tanggungan membebani secara utuh obyeknya, jika sebagian dari utang dibayar maka pembayaran itu tidak membebaskan sebagian dari benda yang dibebani Hak Tanggungan. Penyimpangan

\footnotetext{
6 Isnaeni, Hukum Jaminan Kebendaan: Eksistensi, Fungsi dan Pengaturan, Laksbang Press Indo, Yogyakarta, 2016, h.102.

7 Ibid, h. 99.

8 Ibid, h.109.

9lbid, h.104.
}

terhadap asas ini hanya dapat dilakukan apabila hal tersebut diperjanjikan secara tegas di dalam Akta Pemberian Hak Tanggungan yang bersangkutan. Asas tidak dapat dibagi-bagi dapat disimpangi dalam hal Hak Tanggungan dibebankan pada beberapa hak atas tanah dan pelunasan utang yang dijamin dilakukan dengan cara angsuran sebesar nilai masing-masing hak atas tanah yang merupakan bagian dari obyek Hak Tanggungan yang akan dibebaskan dari Hak Tanggungan tersebut, dengan demikian Hak Tanggungan itu hanya akan membebani sisa obyek Hak Tanggungan untuk sisa utang yang belum dilunasi. Sifat lainnya dari Hak Tanggungan adalah bahwa Hak Tanggungan merupakan accessoir pada perjanjian yang menimbulkan hubungan hukum utangpiutang atau perjanjian kredit yang mendahuluinya, sehingga hapusnya Hak Tanggungan tergantung pada perjanjian pokoknya. Hak Tanggungan dapat dibebankan lebih dari satu kali terhadap obyek yang sama untuk menjamin pelunasan lebih dari satu utang dan untuk beberapa kreditor. Hal ini menimbulkan tingkatantingkatan bagi pemegang Hak Tanggungan, yang ditentukan menurut tanggal pendaftarannya di Kantor Pertanahan.

Terkait kedudukan Ikatan Jual Beli dengan kuasa menjual sebagai jaminan utang, yang mana dalam perjanjian kredit benda tertentu milik Debitor diikat sebagai jaminan oleh kreditor tertentu, tunduk pada Buku II BW yang sifatnya tertutup dan dwingend recht. Hal ini berarti menurut sifatnya maka atas jaminan utang berupa tanah dan bangunan dengan bukti hak Sertifikat Hak Milik tersebut harusnya dibuat dalam bentuk Hak Tanggungan. Pelaksanaan pengikatan jaminan kredit dengan Hak Tanggungan sebagai lembaga jaminan kredit satu-satunya yang dimungkinkan, dan tidak boleh dibuat dalam bentuk jaminan kredit lainnya. Pengikatan jaminan kredit dengan Hak Tanggungan ini pada dasarnya diadakan untuk menjamin pelunasan utang Debitor, karena dengan diadakannya Hak Tanggungan tersebut, maka kreditor dalam hal ini Koperasi mendapat hak untuk didahulukan piutangnya dari Kreditor lain apabila barang yang dibebani dengan Hak Tanggungan tersebut dijual. Meskipun dalam UU Perkoperasian tidak ada satu pasal pun yang mengharuskan bahwa Anggaran Dasar suatu koperasi harus dibuat secara otentik, namun menurut Budi Untung, Anggaran Dasar 
koperasi perlu dibuat dengan otentik agar memiliki kekuatan sebagai alat bukti ${ }^{10}$. Berdasarkan Pasal 1868 BW, akta otentik adalah akta yang dalam bentuk yang ditentukan oleh UU, dibuat oleh atau dihadapan Pejabat Umum yang berwenang untuk itu ditempat dimana akta itu dibuat. Pasal 1868 BW tersebut mensyaratkan agar suatu akta agar memiliki kekuatan bukti otentik maka harus ada kewenangan dari Pejabat Umum dalam hal ini adalah Notaris untuk membuat akta otentik yang bersumber pada Undang-Undang. Kewenangan notaris dalam membuat akta otentik tersebut ada dalam Pasal 1 Undang-Undang Jabatan Notaris yaitu Notaris adalah Pejabat umum yang satu-satunya berwenang untuk membuat akta otentik, mengenai semua perbuatan, perjanjian dan penetapan umum atau oleh yang berkepentingan dikehendaki untuk dinyatakan dalam suatu akta otentik, semuanya sepanjang pembuatan akta ini oleh suatu peraturan umum tidak juga ditugaskan atau dikecualikan kepada pejabat atau orang lain.

Perkembangan koperasi di Indonesia perlu diarahkan sehingga peranannya berdampak dalam perekonomian nasional. Perlu penerapan prinsip-prinsip koperasi dan kaidah usaha ekonomi, sehingga koperasi menjadi organisasi ekonomi yang mantap, demokrasi, otonom, partisipasif, dan berwatak sosial, sehingga berperan pula dalam kehidupan ekonomi rakyat. Pengaruh modal dan penggunaannya pada Koperasi tidak boleh mengaburkan dan mengurangi makna Koperasi, di dalam koperasi penekanan kepentingan kemanusiaan (humanitas) lebih diutamakan daripada kepentingan kebendaan ${ }^{11}$. Budi Untung menegaskan bahwa pengaruh modal dan pelaksanaan koperasi tidak boleh mengaburkan dan mengurangi makna utama koperasi, yang mana tujuan utama koperasi berdasarkan Pasal 3 UU Perkoperasian yaitu memajukan kesejahteraan anggota pada khususnya dan masyarakat pada umumnya serta ikut membangun tatanan ekonomi nasional untuk mewujudkan masyarakat yang maju, adil, dan makmur berdasarkan Pancasila dan Undang-Undang Dasar Negara Republik Indonesia Tahun 1945.

\footnotetext{
10 Budi Untung, Hukum Koperasi dan Peran Notaris Indonesia, Andi, Yogyakarta, 2005, h.30.

11 Ibid, h.39.
}

\section{Simpulan}

Berdasarkan pada hasil dan pembahasan yang telah dijabarkan tersebut, penulis menyimpulkan bahwa kedudukan Ikatan Jual Beli dengan kuasa menjual sebagai jaminan utang di lingkungan koperasi simpan pinjam bertentangan dengan Undang-Undang Republik Indonesia nomor 4 tahun 1996 tentang Hak Tanggungan Atas Tanah Beserta Benda-Benda yang Berkaitan dengan Tanah, dan bertentangan dengan Undang-Undang Republik Indonesia nomor 25 tahun 1992 tentang Perkoperasian, serta berakibat batal demi hukum, dengan alasan-alasan sebagai berikut:

a. Bahwa ketentuan atas jaminan utang yang merupakan bagian dari Hukum Benda berdasarkan normanya memiliki sifat memaksa (dwingend recht), yang artinya bahwa tidak dapat disimpangi sekalipun terdapat kesepakatan oleh para pihak, sehingga membatasi dan melarang siapapun yang hendak membuat jaminan kebendaan dalam bentuk lain selain dari yang diatur dalam ketentuan peraturan perundang-undangan. Satu-satunya lembaga jaminan utang yang diperbolehkan hanya dalam bentuk Hak Tanggungan.

b. Bahwa terkait dengan jaminan utang berupa sertifikat hak atas tanah, sejak berlakunya Undang-Undang Republik Indonesia nomor 4 tahun 1996 tentang Hak Tanggungan Atas Tanah Beserta Benda-benda yang Berkaitan dengan Tanah, maka satu-satunya lembaga jaminan utang yang diperbolehkan hanya dalam bentuk Hak Tanggungan. Hal ini berarti jaminan utang yang dibuat dalam bentuk Ikatan Jual Beli yang disertai dengan kuasa menjual adalah bertentangan dengan hukum, dan secara hukum dinyatakan batal demi hukum karena melanggar syarat obyektif tentang sahnya perjanjian di Pasal 1320 BW.

c. Bahwa praktek Ikatan Jual Beli dengan kuasa menjual di lingkungan koperasi simpan pinjam bertentangan dengan Undang-Undang Republik Indonesia nomor 25 tahun 1992 tentang Perkoperasian, karena tujuan koperasi simpan pinjam berdasarkan Pasal 44 ayat 1 UU Perkoperasian adalah untuk menghimpun dana dan menyalurkannya melalui kegiatan usaha simpan pinjam dari dan untuk anggota koperasi yang bersangkutan, serta koperasi lain 
dan/atau anggotanya. Namun dalam hal seseorang baru menjadi anggota koperasi pada saat berutang kepada koperasi, hal ini menjadi tidak relevan dengan tujuan dasar koperasi sebagaimana diamanatkan dalam UU Perkoperasian tersebut.

\section{Saran}

Berdasarkan simpulan di atas, maka saran yang dapat disampaikan adalah sebagai berikut:

a. Hendaknya Notaris sebagai pejabat umum yang berwenang untuk membuat akta otentik berdasarkan Pasal 1 UndangUndang Republik Indonesia nomor 2 tahun 2014 tentang Perubahan Atas Undang-Undang nomor 30 tahun 2004 tentang Jabatan Notaris, menolak pembuatan Ikatan Jual Beli atas jaminan pembayaran utang dalam hal ini jaminan berupa jaminan kebendaan atas tanah dan bangunan dengan bukti hak Sertifikat Hak Milik, karena hanya dimungkinkan dibuat dalam pembebanan Hak Tanggungan.

b. Hendaknya Debitor lebih teliti dalam melakukan penandatanganan dan/atau persetujuan perjanjian kredit maupun Ikatan Jual Beli, guna menghindari kerugian di kemudian hari akibat dibuatnya Ikatan Jual beli atas jaminan kebendaan berupa tanah dan bangunan dengan bukti hak Sertifikat Hak Milik yang banyak terjadi khususnya dalam lingkungan Koperasi Simpan Pinjam, dengan tujuan kreditor untuk memperoleh keuntungan sebesarbesarnya atas kondisi debitor yang tidak memiliki daya tawar.

c. Hendaknya kreditor di dalam perjanjian kredit utang-piutang dengan jaminan berupa jaminan kebendaan atas tanah dan bangunan dengan bukti hak Sertifikat Hak Milik, tidak memanfaatkan keadaan debitor yang gagal bayar dan tidak ada daya tawar untuk melakukan pemenuhan prestasi atau pembayaran utang lewat Ikatan Jual Beli dengan kuasa menjual atas obyek jaminan, karena sifat jaminan kebendaannya yang tertutup dan memaksa, yaitu hanya boleh dalam bentuk Hak Tanggungan, dan apabila tetap terjadi Ikatan Jual Beli atas jaminan kebendaan atas tanah dan bangunan dengan bukti hak Sertifikat Hak Milik sebagai jaminan utang, maka Ikatan Jual
Beli sebagai perjanjian accessoir menjadi batal demi hukum.

d. Penulis juga memberikan masukan terhadap Koperasi Simpan Pinjam, yaitu untuk menghindari praktek Ikatan Jual Beli atas perjanjian kredit yang menggunakan jaminan kebendaan berupa tanah dan bangunan dengan bukti hak Sertifikat Hak Milik, karena tidak dimungkinkan selain melalui pembebanan Hak Tanggungan. Juga atas Ikatan Jual Beli tersebut akan batal demi hukum karena tidak terpenuhinya syarat obyektif dari syarat sahnya suatu perjanjian.

e. Hendaknya pengawas koperasi lebih meningkatkan pengawasannya, untuk memastikan pengurus koperasi menjalankan kegiatan operasional koperasi sesuai dengan ketentuan peraturan perundang-undangan yang berlaku. Selanjutnya fungsi pengawasan terhadap koperasi juga hendaknya ditingkatkan oleh Kementrian Koperasi dan UKM baik dari Pemerintah Pusat, maupun Pemerintah Daerah pada khususnya. Serta pentingnya penyuluhan kepada koperasi dan masyarakat secara terus menerus agar tercipta budaya hukum koperasi yang sesuai dengan konsep hukum perkoperasian Indonesia.

\section{Daftar Pustaka}

Adrian Sutedi, Hukum Hak Tanggungan, Sinar Grafika, Jakarta, 2010.

Budi Untung, Hukum Koperasi dan Peran Notaris Indonesia, Andi, Yogyakarta, 2005.

Isnaeni, Hukum Jaminan Kebendaan: Eksistensi, Fungsi dan Pengaturan, Laksbang Press Indo, Yogyakarta, 2016.

Selintas Pintas Hukum Perikatan,

PT Revka Petra Media, Surabaya, 2017.

Johnny Ibrahim, Teori \& Metodologi Penelitian Hukum Normatif, Bayu Media, Surabaya, 2005.

Peter Mahmud Marzuki, Penelitian Hukum, Prenada Media Group, Jakarta, 2010.

Undang-Undang Dasar Negara Republik Indonesia Tahun 1945. 
Undang-Undang Republik Indonesia nomor 5 tahun 1960 tentang Peraturan Dasar Pokok-Pokok Agraria.

Undang-Undang Republik Indonesia nomor 25 tahun 1992 tentang Perkoperasian.

Undang-Undang Republik Indonesia nomor 4 tahun 1996 tentang Hak Tanggungan Atas Tanah Beserta Benda-benda yang Berkaitan dengan Tanah.

Undang-Undang Republik Indonesia nomor 2 tahun 2014 tentang Perubahan Atas Undang-Undang nomor 30 tahun 2004 tentang Jabatan Notaris. 